Grant H Lundberg

Brigham Young University

\title{
Preliminary Report on Dialect Attitudes in Austrian and Slovene Carinthia
}

This paper is a preliminary analysis of an internet-based questionnaire on dialect attitudes and perceptions conducted in Slovene-speaking areas in Austrian and Slovene Carinthia.

Prispevek prinaša uvodno analizo internetne ankete o odnosu do narečij in o sprejemanju narečij, narejene na slovensko govorečih področjih avstrijske in slovenske Koroške.

\section{Introduction}

It is well known that the Slovene language situation is variegated, made up of a complicated interaction between multiple local dialects, regional dialects, the colloquial standard and the literary language. Even with this complicated interaction and the growing influence of the literary language and the regional dialect of Central Slovenia, several recent surveys of relatively large numbers of Slovenes indicate that large majorities of respondents claim to be fluent in and regularly use the local dialect (Lundberg 2010, 2013). These surveys are uniform in showing that the local dialect plays an important role in local identity in Slovenia. There do seem to be differences in dialect usage patterns and the influence of different varieties of Slovene on the local dialect based on the region of origin of the respondents. These variations are particularly noticeable in the peripheral dialect regions (Lundberg 2014: 248). This study is based on a preliminary analysis of a questionnaire on dialect attitudes and perceptions of use in one such peripheral dialect region, the Slovene-speaking areas in Austrian and Slovene Carinthia, hereafter Koroška. ${ }^{1}$

\section{Survey}

During the late summer and fall of 2014, a Qualtrics internet-based survey on language attitudes and usage patterns was distributed in Austrian and Slovene

${ }^{1}$ Much has been written about the categorization and phonological structure of micro-dialects in both Austrian and Slovene Carinthia. These studies are not referenced here because my focus is the attitudes and perceptions of the dialect speakers themselves rather than descriptive dialectology. For some discussion of the structure of Carinthian dialects, see Neweklowsky 1999, Pronk 2009 and Zorko 2009. 
Koroška. ${ }^{2}$ The complete survey can be found in an appendix at the end of this article. ${ }^{3} 282$ complete responses were collected. Two-thirds of respondents were from Slovene Koroška. Respondents were nearly split for gender, $56 \%$ female and $44 \%$ male. $23 \%$ of respondents were between 18 and 30; 36\% were between 31 and 50; $31 \%$ were between 51 and 65 ; only $2 \%$ were younger than 18 , and $8 \%$ were older than 65 . The level of education of respondents was rather high. $12 \%$ of respondents had only primary school or a basic vocational education. $47 \%$ had completed secondary education, and $41 \%$ had some form of post-secondary education.

\section{Dialect Usage}

The first part of the survey deals with dialect usage and attitudes. These questions focus on how well and how often people use dialect and whether or not dialect is important to local identity. As the title of the paper indicates, this is only a preliminary analysis using simple descriptive statistics. More sophisticated statistical analyses based on this and similar surveys will need to follow.

Chart 1: Proficiency in Dialect

My command of my local dialect is:

\begin{tabular}{lcc} 
Answer & Response & $\%$ \\
\hline Good & 261 & $93 \%$ \\
Adequate & 12 & $4 \%$ \\
Weak & 8 & $3 \%$ \\
Zero & 1 & $0 \%$ \\
\hline Total & 282 & $100 \%$
\end{tabular}

Chart 1 depicts the first question examined in this study. In the survey the possible answers to this question were accompanied by a short explanation in parenthesis: good (speak and understand), adequate (understand and can make myself understood), weak

${ }^{2}$ I was assisted in the distribution of the questionnaire by Slovenski tednik za koroško and Koroške novice. Both publications placed a link for my survey on their webpages and encouraged participation on their Facebook sites. The survey was open to any Koroško dialect speaker.

${ }^{3}$ I would like to thank Tom Priestly for his advice and help in finding contacts in the Slovene community in Austria, where he has an extensive network. I would also like to thank Milena Olip of Sele/Zell. She was very kind to show me around and introduce me to people in her community. I am grateful to Jasna Černjak who showed me around and introduced me to people in Mežica near Ravne na Koroškem on the Slovene side of the border. The bulk of the data for this study comes from the online survey, but it was helpful to interview dialect speakers on both sides of the border to help clarify survey results. Finally, I would like to thank the anonymous reviewers of this article. The paper is better because of their comments. Any mistakes or shortfalls in the study are my own. 
(only understand), zero. Based on these explanations, 93\% of respondents claimed to be fluent in their local dialect. ${ }^{4}$ Most of the age and education categories responded in a similar way. $83 \%$ of those under 18 claimed to have the highest level of command of the local dialect, and $17 \%$ claimed weak command. It is not surprising that younger people claim to be less proficient in the local dialect. There is an interesting difference based on gender. $89 \%$ of men and $95 \%$ of women claimed the highest level of command of the local dialect. There are some interesting differences if we look at the results based on where the respondents live. There is a small but interesting difference in attitudes and perceptions about the level of fluency in the local dialect in Austrian Koroška. Only 87\% of those from the Austrian side of the border claimed the highest level of proficiency in the local dialect.

Chart 1.1: Proficiency in Dialect by Region

\begin{tabular}{lcc} 
Answer & Slovene Koroška & Austrian Koroška \\
\hline Good & $96 \%$ & $87 \%$ \\
Adequate & $2 \%$ & $9 \%$ \\
Weak & $2 \%$ & $3 \%$ \\
Zero & $0 \%$ & $1 \%$ \\
\hline Total & 175 & 69
\end{tabular}

The second question examined in this study asks which variant of the language respondents primarily speak. When asked what variant of the language they used most of the time, $60 \%$ of respondents said that they spoke in dialect, $28 \%$ said that they used the regional spoken language of their area or of the largest city in the region, and only $6 \%$ claimed to use the colloquial standard language. $3 \%$ claimed to use German. We will return to this figure when we examine responses based on where people live.

Chart 2: Usage

I primarily speak:

\begin{tabular}{lcl} 
Answer & Response & $\%$ \\
\hline Dialect & 170 & $60 \%$ \\
Colloquial Standard & 16 & $6 \%$ \\
Regional Dialect & 78 & $28 \%$ \\
Other & 9 & $3 \%$ \\
German & 9 & $3 \%$ \\
\hline Total & 282 & $100 \%$
\end{tabular}

${ }^{4}$ This can be compared to a larger survey of 1786 Slovenes from all major dialect groups published in 2014. In this survey $90 \%$ claimed good and $8 \%$ claimed adequate knowledge of the local dialect (Lundberg: 244). 
Chart 2 gives a good indication of the every-day dominance of the local dialect and the regional dialect in this area. ${ }^{5}$ It is also interesting that a number of people commented that they did not speak only one variant of the language but several based on the circumstances or a mixture of several. On the Austrian side of the border, people often claimed to speak dialect with the family and German in other local situations. On the Slovene side of the border, people often claimed to speak a mixture of local dialect, the regional dialect and some elements of the colloquial standard. When analyzed by age only $50 \%$ of the youngest and the oldest respondents claimed to primarily speak in the local dialect. $14 \%$ of those over 65 claimed to primarily speak German. We will look at this again when we analyze the responses according to residence. In this survey education level was related to a decrease in the percentage of those who claimed to primarily speak in the local dialect. $69 \%$ of those with the lowest level of education claimed to primarily speak dialect, $63 \%$ of those with secondary or college-prep education claimed to mainly use dialect, and $55 \%$ of those with post-secondary education claimed to primarily speak in the local dialect.

Chart 2.1: Usage by Region

\begin{tabular}{lcc} 
Answer & Slovene Koroška & Austrian Koroška \\
\hline Dialect & $61 \%$ & $65 \%$ \\
Colloquial Standard & $5 \%$ & $6 \%$ \\
Regional Dialect & $34 \%$ & $13 \%$ \\
Other & $0 \%$ & $4 \%$ \\
German & $0 \%$ & $12 \%$ \\
\hline Total & 175 & 69
\end{tabular}

In Austrian Koroška $65 \%$ of respondents claimed to primarily use the local dialect, and $12 \%$ claimed to mainly use German. The regional dialect seems to be used less commonly as a standard means of communication in Austrian Koroška as opposed to on the Slovene side of the border. This is likely due to the fact that German fills the role for communication outside of the local dialect area.

Chart 3: Youth and Dialect

Do the youth of your area primarily speak dialect?

\begin{tabular}{lcc} 
Answer & Response & $\%$ \\
\hline Yes & 212 & $76 \%$ \\
No & 66 & $24 \%$ \\
\hline Total & 278 & $100 \%$
\end{tabular}

${ }^{5}$ This differs from the results of the larger survey of the entire country cited earlier. In that larger survey $51 \%$ of respondents claimed to speak most of the time in the regional dialect, $24 \%$ claimed to use the local dialect primarily, and $20 \%$ claimed to speak the colloquial standard language most of the time. 
The next question deals with language choice among the youth of the area. $76 \%$ of respondents claimed that the youth of their area primarily spoke in the local dialect. These responses seem to indicate that most Korošci believe that their local dialects are robust and functional and that they speak most of the time in the regional dialect or local dialect rather than in the colloquial standard language. The responses were in the high 70s and low 80s for all age and education categories except for those over 65 and with some post-secondary education. Only $43 \%$ of the oldest respondents and $67 \%$ of the most educated claimed that the youth of their region primarily spoke the local dialect. $68 \%$ of men and $82 \%$ of women claimed that the youth spoke primarily in the local dialect. Again, there is a striking difference in the results when we separate the responses based on where people live. A majority of respondents from the Austrian side did not indicate that the youth of the area primarily spoke the local dialect.

Chart 3.1: Youth and Dialect by Region

\begin{tabular}{lcc} 
Answer & Slovene Koroška & Austrian Koroška \\
\hline Yes & $92 \%$ & $43 \%$ \\
No & $8 \%$ & $57 \%$ \\
\hline Total & 172 & 68
\end{tabular}

As an additional way to gage the value respondents place on the local dialect, people were asked to indicate the importance of the dialect to local identity.

Chart 4: Identity

For my identity the local dialect is:

\begin{tabular}{lcl} 
Answer & Response & $\%$ \\
\hline Very Important & 226 & $80 \%$ \\
Somewhat Important & 48 & $17 \%$ \\
Unimportant & 7 & $2 \%$ \\
\hline Total & 281 & $100 \%$
\end{tabular}

The responses were very similar for all age and education categories with the exception of respondents under 18 . In that category $33 \%$ claimed the dialect was very important for their identity, and $67 \%$ claimed it was somewhat important. $85 \%$ for men and $78 \%$ of women claimed the local dialect was very important to their identity. The responses were also similar based on residence in Austrian or Slovene Koroška. 
Chart 4.1: Identity by Region

\begin{tabular}{lcc} 
Answer & Slovene Koroška & Austrian Koroška \\
\hline Very Important & $82 \%$ & $84 \%$ \\
Somewhat Important & $16 \%$ & $14 \%$ \\
Unimportant & $2 \%$ & $2 \%$ \\
\hline Total & 174 & 69
\end{tabular}

Large majorities on both sides of the border claimed to use and value the local dialect. Lower percentages in Austrian Koroška claimed proficiency and that the youth of the area primarily spoke the local dialect. This should not be surprising. Although there may be some positive indicators for dialect maintenance in Austrian Koroška, a consistent decline in the number of speakers has been reported in various studies (Priestly and Comanaru).

\section{Influence of Other Varieties of Slovene}

The second part of the survey deals with perceptions about the influence of other varieties of Slovene on the local dialect. Because the attitudes Slovenes hold toward their own and other dialect areas are important in language change and maintenance (Preston: xxiv), as an introduction to this part of the survey, informants were asked to indicate where the most beautiful and the least comprehensible Slovene were spoken. ${ }^{6}$

Chart 5: Beautiful Slovene

Where is the most beautiful Slovene spoken?

\begin{tabular}{lcc} 
Answer & Response & $\%$ \\
\hline 1. Primorska & 19 & $7 \%$ \\
\hline 2. Rovtarska & 3 & $1 \%$ \\
\hline 3. Gorenjska & 22 & $8 \%$ \\
\hline 4. Koroška & 92 & $34 \%$ \\
\hline 5. Dolenjska & 23 & $8 \%$ \\
\hline 6. Štajerska & 55 & $20 \%$ \\
\hline 7. Panonska & 5 & $2 \%$ \\
8. Maribor & 8 & $3 \%$ \\
\hline 9. Osrednja Slovenija & 45 & $17 \%$ \\
\hline Total & 272 & $100 \%$
\end{tabular}

${ }^{6}$ One of the anonymous reviewers of the paper was concerned that the dialect maps, dialect and language categories and some of the linguistic terminology are imprecise. I acknowledge that this is a valid critique, but I want to emphasis that the study and paper were designed this way intentionally because of the focus of the research, which is perceptual. The survey categories and terms needed to be accessible to a non-linguist without a background in Slovene dialectology. Much precision is sacrificed in this process, but valuable information about attitudes toward language varieties can be collected. 
It should not be surprising that respondents choose their own dialect area as the place where the most beautiful Slovene was spoken. It might be surprising that Stajerska was judged to be the next most beautiful. This is a similar result to one recorded in an earlier survey (Lundberg 2007: 103). It should be noted that the secondary literature indicates that the answer to this question may not be only an aesthetic judgment. Beauty in language is often associated with correctness. The closer a dialect is to the standard language, the more likely it will be considered beautiful (Kontra 2002: 206). Intelligibility also correlates with beauty. That is one of the reasons that people often judge the standard language and their own dialect as beautiful (van Bezooijen 2002: 15). There are many Slovenes who consider the colloquial language spoken around Celje to be a good model of correct language. ${ }^{7}$

The responses to this question were very similar to those depicted above when analyzed based on age, education level and gender. The most striking difference for place of residence is that a much larger percentage of respondents focused on Koroška as the most beautiful Slovene for those living in Austria, likely indicating less familiarity with or exposure to other varieties of Slovene.

Chart 5.1: Beautiful Slovene by Region

\begin{tabular}{lcc} 
Answer & Slovene Koroška & Austrian Koroška \\
\hline 1. Primorska & $5 \%$ & $7 \%$ \\
2. Rovtarska & $0 \%$ & $3 \%$ \\
\hline 3. Gorenjska & $7 \%$ & $16 \%$ \\
4. Koroška & $31 \%$ & $48 \%$ \\
\hline 5. Dolenjska & $8 \%$ & $10 \%$ \\
6. Štajerska & $26 \%$ & $5 \%$ \\
\hline 7. Panonska & $2 \%$ & $0 \%$ \\
\hline 8. Maribor & $2 \%$ & $3 \%$ \\
\hline 9. Osrednja Slovenija & $19 \%$ & $8 \%$ \\
\hline Total & 173 & 62
\end{tabular}

The least comprehensible version of Slovene was overwhelmingly seen as Panonska (64\%). This holds true for all categories of age, education, gender and residence. This is also a regularly repeated result in other surveys (Lundberg 2007: 104).

${ }^{7}$ In a pilot version of the 2007 questionnaire cited above, I asked 40 students where the most correct and incorrect Slovene was spoken. The top answers for most correct and incorrect in the pilot study were Štajerska and Prekmurje, respectively. The full study of nearly 500 Slovenes gave the same results. 
Chart 6: Least Comprehensible Slovene

\begin{tabular}{lcc}
\hline Answer & Response & $\%$ \\
\hline 1. Primorska & 20 & $8 \%$ \\
\hline 2. Rovtarska & 24 & $9 \%$ \\
\hline 3. Gorenjska & 6 & $2 \%$ \\
\hline 4. Koroška & 10 & $4 \%$ \\
\hline 5. Dolenjska & 11 & $4 \%$ \\
\hline 6. Štajerska & 10 & $4 \%$ \\
\hline 7. Panonska & 169 & $64 \%$ \\
\hline 8. Maribor & 3 & $1 \%$ \\
\hline 9. Osrednja Slovenija & 12 & $5 \%$ \\
\hline Total & 265 & $100 \%$
\end{tabular}

When asked with which variety of Slovene, other than the local dialect, respondents had the most contact, $48 \%$ claimed to have the most contact with the colloquial standard, defined as the way people speak on television. $17 \%$ said they had the most contact with the regional dialect of Central Slovenia, and 17\% said they had the most contact with the regional spoken language of their area.

Chart 7: Contact

With which version of the language other than your local dialect do you have the most contact?

\begin{tabular}{lcc} 
Answer & Response & $\%$ \\
\hline Colloquial Standard & 133 & $48 \%$ \\
Dialect of Central Slovenia & 46 & $17 \%$ \\
\hline Dialect of Maribor & 36 & $13 \%$ \\
Regional Dialect & 48 & $17 \%$ \\
Other & 14 & $5 \%$ \\
\hline Total & 277 & $100 \%$
\end{tabular}

Several respondents from the Austrian side of the border chose "Other" and clarified that they had contact with a regional Slovene dialect from Austrian Koroška, e.g., Podjunsko, rather than Slovene Koroška.

The results depicted in chart 7 are consistent with findings in earlier studies in which respondents from peripheral dialects regions felt the closest and most frequent contact with the standard language, probably through television and radio (Lundberg 2014: 248). 
For all age categories the top choice was the colloquial standard. The second highest choice for those under 18 and between 18 and 30 was the dialect of Maribor and its surroundings. This likely has to do with the location of institutions of secondary education for young people from this area. The second choice for respondents between 31 and 50 was the Koroška regional dialect. For those between 51 and 65 and 65 and above the second highest choice was the dialect of Central Slovenia. In chart 7.1 we see a similar break down for education level. The top choice is very similar for all. The second choice for the least educated is the dialect in and around Maribor. The second choice for the middle group is the regional dialect, and the second choice for those with post-secondary education is the dialect of Central Slovenia.

Chart 7.1: Contact by Education

\begin{tabular}{lccc} 
Answer & Primary/Vocational & Secondary & Post-Secondary \\
\hline Colloquial Standard & $49 \%$ & $46 \%$ & $50 \%$ \\
Dialect of Central Sln & $6 \%$ & $15 \%$ & $21 \%$ \\
Dialect of Maribor & $24 \%$ & $15 \%$ & $8 \%$ \\
Regional Dialect & $15 \%$ & $22 \%$ & $13 \%$ \\
Other & $6 \%$ & $2 \%$ & $8 \%$ \\
\hline Total & 33 & 129 & 114
\end{tabular}

Female respondents seem to be more locally oriented than male respondents for this question. $43 \%$ of women claimed to have the most contact with the colloquial standard, and $21 \%$ claimed the most contact with the Koroška regional dialect. $54 \%$ of men claimed to have the most contact with the colloquial standard. For men the second highest choice was the dialect of Central Slovenia with $18 \%$.

Chart 7.2: Contact by Region

\begin{tabular}{lcc} 
Answer & Slovene Koroška & Austrian Koroška \\
\hline Colloquial Standard & $46 \%$ & $55 \%$ \\
Dialect of Central Sln & $15 \%$ & $20 \%$ \\
Dialect of Maribor & $19 \%$ & $0 \%$ \\
Regional Dialect & $18 \%$ & $13 \%$ \\
Other & $2 \%$ & $12 \%$ \\
\hline Total & 170 & 69
\end{tabular}

Again, as seen in chart 7.2, respondents from the Austrian side of the border claimed to have relatively more contact with the colloquial standard language, most likely as a result of influence from television and radio, than with other varieties of Slovene as compared to respondents from Slovene Koroška. 
Chart 8: Dialect Loss

Is Your Dialect Dying?

\begin{tabular}{lcc} 
Answer & Response & $\%$ \\
\hline Yes & 130 & $47 \%$ \\
No & 149 & $53 \%$ \\
\hline Total & 279 & $100 \%$
\end{tabular}

When asked if their dialect was dying, 53\% of respondents said no. This result from Koroška is significantly different from the response to this question in surveys of other Slovene dialect areas, in which large majorities claimed that the dialect was not dying. ${ }^{8}$ People are hopeful and yet unsure about the future of dialect. They claim to continue to speak it, but they know it is not the same dialect as that of the older generations. Many people think of it more as a regional variety than the micro dialect of the village. The following comment from an earlier survey of another dialect region makes this point, one which is made often in different forms. "V zgornjem odgovoru sem imela $\mathrm{V}$ mislih izumiranje našega "vaškega" jezika. Prihajam iz majhne vasice, ki se nahaja na območju Čičarije in Brkinov. Včasih je tu vsaka vas imela svojo obliko narečja, in to se je v naši vasi skoraj izgubilo (govori ga le še moja babica in nekaj starejših vaščanov), mladi ga ne govorimo ali sploh ne poznamo. Ne izumira pa širše primorsko narečje." People believe that the regional dialect is not dying, but they acknowledge that the village dialect of their grandparents is hardly spoken anymore (Lundberg 2014: 248). All age and education categories responded in the range of $40 \%$ that the dialect was dying with the exception of the oldest and most educated. $51 \%$ of respondents between 51 and 65 and $76 \%$ of those over 65 claimed the dialect was dying. 51\% of those with post-secondary education claimed the dialect was dying. $41 \%$ of women and $54 \%$ of men claimed the dialect was dying. We see the biggest difference when we break this question down by residence. In chart 8.1 we see that $75 \%$ of respondents living in Austrian Koroška claimed that the local dialect was dying. This is another indication that attitudes about dialect maintenance on the Austrian side of the border are less positive.

Chart 8.1: Dialect Loss by Region

\begin{tabular}{lcc} 
Answer & Slovene Koroška & Austrian Koroška \\
\hline Yes & $35 \%$ & $75 \%$ \\
No & $65 \%$ & $25 \%$ \\
\hline Total & 173 & 68
\end{tabular}

\footnotetext{
${ }^{8}$ See the 2014 survey cited earlier.

9 'In the above answer I had in mind the death of our village language. I come from a very small village in the region of Čičarija in Brkini. Earlier each village had its own form of dialect, and this has been almost completely lost in our village (only my grandmother and a few others still speak it). Young people don't speak it and hardly understand. The wider Primorsko dialect is not dying.'
} 
Those who answered that the dialect was dying were asked what variety of the language was replacing it.

Chart 9: Replacing Dialect

What version of the language is replacing your local dialect?

\begin{tabular}{lcc} 
Answer & Response & $\%$ \\
\hline Colloquial Standard & 26 & $18 \%$ \\
\hline Dialect of Central Slovenia & 19 & $13 \%$ \\
Dialect of Maribor & 3 & $2 \%$ \\
Regional Dialect & 24 & $17 \%$ \\
Other & 18 & $13 \%$ \\
German & 53 & $37 \%$ \\
\hline Total & 143 & $100 \%$
\end{tabular}

$37 \%$ claimed the dialect is being replaced by German. $18 \%$ claimed that the colloquial standard language was replacing the local dialect, $17 \%$ said the regional spoken language of their area was replacing the dialect, and $13 \%$ said it was the regional dialect of Central Slovenia. This result is interesting but a bit misleading in isolation. This question was answered only by those who claimed the dialect was dying. This is the influence of respondents from Austrian Koroška, where $75 \%$ of respondents answered that the local dialect was dying. If we analyze the responses according to place of residence, we see that $80 \%$ of those living in Austrian Koroška claimed that German is replacing the local dialect, but in Slovene Koroška 34\% claimed it is being replaced by the colloquial standard, and 29\% claimed the local dialect is being replaced by the regional Koroška dialect. This is much more in line with similar surveys of other regions within Slovenia.

Chart 9.1: Dialect Replacement by Region

\begin{tabular}{lcc} 
Answer & Slovene Koroška & Austrian Koroška \\
\hline Colloquial Standard & $34 \%$ & $3 \%$ \\
Dialect of Central Sln & $19 \%$ & $5 \%$ \\
Dialect of Maribor & $4 \%$ & $0 \%$ \\
Regional Dialect & $29 \%$ & $5 \%$ \\
Other & $13 \%$ & $7 \%$ \\
German & $1 \%$ & $80 \%$ \\
\hline Total & 70 & 54
\end{tabular}

Because the basic numbers are weighted toward responses from Austrian Koroška, the analysis by age and education don't look substantially different, again with the exception of the oldest and most educated respondents. $56 \%$ of those over 65 and 
$55 \%$ of those with post-secondary education claimed German was replacing the local dialect as opposed to percentages in the 20 s and 30 s for all other categories. $51 \%$ of men and $22 \%$ of women claimed German was replacing the local dialect. $14 \%$ of men and $22 \%$ of women claimed it was being replaced by the colloquial standard. $22 \%$ of women claimed the local dialect was being replaced by the regional Koroška dialect. Overall a relatively large percentage of respondents from Koroška claimed the local dialect was dying, 35\% in Slovene Koroška and 75\% in Austrian Koroška. Respondents claimed to have the most contact with the colloquial standard and that the local dialect is being replaced by the colloquial standard or, on the Austrian side of the border, by German. It appears likely that the local dialects in Koroška are being leveled toward the standard language rather than toward the regional dialect. These are not positive indicators for dialect maintenance, especially in Austrian Koroška, where the variety of Slovene spoken, to the extent that Slovene is spoken rather than German, will more likely be the colloquial standard language rather than a local dialect or a regional dialect.

\section{References}

Kontra, Miklos. 2002. "Where is the 'Most Beautiful' and the 'Ugliest' Hungarian Spoken?" Handbook of Perceptual Dialectology, Volume 2. (ed. Daniel Long and Denis Prestion): 205-18. Amsterdam, Netherlands: Benjamins.

Lundberg, Grant H. 2014. "Dialect Leveling and Local Identity in Slovenia." New Insights into Slavic Linguistics. (ed. Jacek Witkoś and Sylwester Jaworski): 241-52. Frankfurt am Main: Peter Lang.

--. 2013. Dialect Leveling in Haloze, Slovenia (Zora 91). Maribor: Mednarodna knjižna zbirka ZORA.

--. 2010. "Dialect Usage in Slovenia." Slovene Studies 32/1-2: 43-66.

--. 2007. "Perceptual Dialectology and the Future of Slovene Dialects." Slovenski jezik / Slovene Linguistic Studies 6: 97-109.

Neweklowsky, Gerhard. 1999. "Iz zgodovine klasifikacije slovenskih narečij na Koroškem in nove naloge slovenske dialektologije." in Logarjev zbornik (ed. Zinka Zorko and Mihaela Koletnik). 16-26. Maribor: Zora.

Preston, Denis. 1999. "Introduction.” Handbook of Perceptual Dialectology, Volume 1. (ed. Denis Preston): xxiii-xl. Amsterdam: Benjamins.

Priestly, Tom and Ruxandra Comanaru. 2009. "Identity among the Minority Slovenes of Carinthia, Austria." Rasprave in gradivo 28: 6-23.

Pronk, Tijmen. 2009. The Slovene Dialect of Egg and Potschach in the Gailtal, Austria. Amsterdam: Rodopi.

Van Bezooijen, Renee. 2002. "Aesthetic Evaluations of Dutch: Comparisons across Dialects, Accents and Languages." Handbook of Perceptual Dialectology, Volume 2. (ed. Daniel Long and Denis Preston): 13-30. Amsterdam, Netherlands: Benjamins.

Zorko, Zinka. 2009. "Koroško mižiško narečje v luči novih glasoslovnih raziskav." Slavia centralis (2): 33-49. 


\section{Appendix 1}

\section{Slovene Dialect Contact - Koroška}

Z anketo bi želeli ugotoviti, kakšen odnos imajo ljudje v Sloveniji do krajevnega narečja. Anketa je anonimna, $\mathrm{z}$ njo zbrani podatki pa bodo uporabljeni izključno v raziskovalne namene. Za sodelovanje se vam avtor že vnaprej lepo zahvaljuje.

Q1 Svoje slovensko krajevno narečje obvladam:

- dobro (govorim in razumem). (1)

- zadostno (razumem in se za silo sporazumevam). (2)

- slabo (samo razumem). (3)

- nič. (4)

Q2 V svojem kraju večinoma govorim:

- v slovenskem krajevnem narečju. (1)

- v slovenskem knjižnem pogovornem jeziku. (2)

- v slovenskem pogovornem jeziku svojega kraja. (3)

- v nemščini (5)

- drugo (pojasnite). (4)

Q3 Ali mladina vašega kraja večinoma govori v slovenskem narečju?

- Da. (1)

- Ne (pojasnite).

Q4 Za mojo identiteto in pokrajinsko pripadnost je krajevno narečje:

- zelo pomembno (1)

- malo pomembno (2)

- nepomembno (3)

Q5 Kje v Sloveniji po vašem mnenju govorijo najlepšo slovenščino?

- 1. Primorska (1)

- 2. Rovtarska (2)

-3. Gorenjska (3)

-4. Koroška (4)

- 5. Dolenjska (5)

-6. Štajerska (6)

- 7. Panonska (7)

- 8. Maribor (8)

- 9. Osrednja Slovenija (9) 


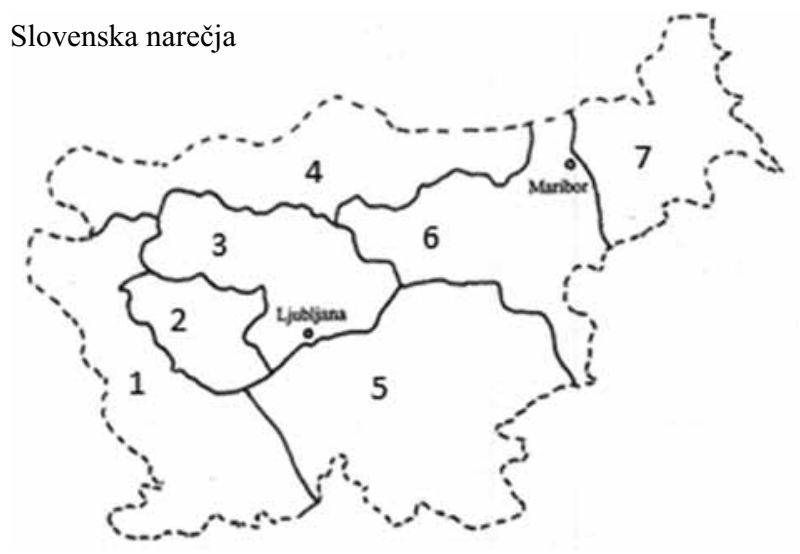

Q6 Kje v Sloveniji po vašem mnenju govorijo najbolj nerazumljivo slovenščino?

- 1. Primorska (1)

- 2. Rovtarska (2)

-3. Gorenjska (3)

- 4. Koroška (4)

- 5. Dolenjska (5)

- 6. Štajerska (6)

- 7. Panonska (7)

- 8. Maribor (8)

-9. Osrednja Slovenija (9)

Q7 S katero zvrstjo slovenskega jezika ste poleg vašega krajevnega narečja najpogosteje v stiku?

- S knjižnim pogovornim (kot govorijo na televiziji). (1)

- S pogovornim jezikom osrednje Slovenije. (2)

- S pogovornim jezikom Maribora in okolice. (3)

- S pogovornim jezikom največjega mesta vašega kraja in okolice. (4)

- Drugo (pojasnite). (5)

Q8 Ali vaše krajevno narečje izumira?

- Da. (1)

- Ne. (2)

Q9 Če ste na zadnje vprašanje odgovorili z da, katera vrsta jezika nadomešča narečje?

- Knjižni pogovorni (kot govorijo na televiziji). (1)

- Pogovorni jezik osrednje Slovenije. (2)

- Pogovorni jezik Maribora in okolice. (3)

- Pogovorni jezik največjega mesta vašega kraja in okolice. (4)

- Nemščina (7)

- Drugo (pojasnite). (5) 
Q10 V točkah 10 in 11 ocenite z 1 do 7 vaš odnos do izjave. Npr. pri nasprotju grdo-lepo 1 pomeni najgrše, 7 pa najlepše.Vaše krajevno narečje je grdo - lepo.

- $1(1)$

- $2(2)$

- $3(3)$

$\cdot 4(4)$

$\cdot 5(5)$

$6(6)$

$\cdot 7(7)$

Q11 Človek, ki ni iz vašega kraja, najbrž misli, da je vaše narečje grdo - lepo.

- $1(1)$

- $2(2)$

-3(3)

$\cdot 4(4)$

$\cdot 5(5)$

$\cdot 6(6)$

- 7 (7)

Q12 Spol:

- m. (1)

- ž. (2)

\section{Q13 Starost:}

- mlajši od 18 let (1)

- od 18 do 30 (2)

- od 31 do 50 (3)

- od 51 do 65 (4)

- več kot 65 let (5)

Q14 Vaša stopnja izobrazbe:

- osnovna ali poklicna šola. (1)

- srednja ali višja šola. (2)

- vis. šola, univerza, podipl. študij. (3)

Q15 Kje ste se rodili?

- Na slovenskem Koroškem (1)

- Na avstrijskem Koroškem (3)

- Drugje (Kje?) (2)

Q16 Kje zdaj živite?

- Na slovenskem Koroškem (1)

- Na avstrijskem Koroškem (3)

- Drugje (Kje?) (2)

Prispelo aprila 2015, sprejeto junija 2015

Received April 2015, accepted June 2015 


\section{Preliminary Report on Dialect Attitudes in Austrian and Slovene Carinthia}

This paper is a preliminary analysis of an internet-based questionnaire on dialect attitudes and perceptions conducted in Slovene-speaking areas in Austrian and Slovene Carinthia. The survey largely confirmed expectations. Large majorities on both sides of the border claimed to use and value the local dialect. Lower percentages in Austrian Carinthia claimed proficiency in the local dialect and that the youth of Austrian Carinthia primarily spoke the local dialect. Overall a relatively large percentage of respondents from Carinthia claimed the local dialect was dying, 35\% in Slovene Carinthia and $75 \%$ in Austrian Carinthia. Respondents claimed that the local dialect is being replaced by the colloquial standard language or, on the Austrian side of the border, by German. It appears likely that the local dialects in Carinthia are being leveled toward the standard language rather than toward the regional dialect. These are not positive indicators for dialect maintenance, especially in Austrian Carinthia.

\section{Uvodna analiza o odnosu do narečij v avstrijski in slovenski Koroški}

Prispevek prinaša uvodno analizo internetne ankete o odnosu do narečij in o sprejemanju narečij, narejene na slovensko govorečih področjih avstrijske in slovenske Koroške. Rezultati ankete so v veliki meri potrdili pričakovane rezultate. Velika večina anketirancev na obeh straneh meje zatrjuje, da uporablja in ceni lokalno narečje. Manjši odstotek v avstrijski Koroški meni, da odlično obvlada lokalno narečje in da mladi tam govorijo predvsem lokalno narečje. Nasploh pa je delež odgovorov, ki meni, da lokalno narečje umira, razmeroma velik: 35 \% na slovenskem Koroškem in $75 \%$ na avstrijskem Koroškem. Anketiranci menijo, da lokalno narečje izpodriva splošni pogovorni jezik na Slovenskem oziroma nemščina v Avstriji. Kaže, da se lokalna narečja v večji meri približujejo splošnemu pogovornemu jeziku kakor regionalnemu narečju. Takšen razvoj ni dober za ohranitev narečij, še posebej v avstrijski Koroški. 